\title{
Batch and Flow Injection Spectrophotometric Determination of Doxycycline Hyclate in Pharmaceutical Preparations
}

\author{
Mouayed Q. Al-Abachi and Zaid A. Al-Nedawi ${ }^{1}$ \\ Department of Chemistry, College of Science, University of Baghdad, Baghdad-Iraq. \\ E-mail: zaid.abdulsatar@yahoo.com.
}

\begin{abstract}
New, simple and sensitive batch and flow injection spectrophotometric methods for the determination of doxycycline hyclate $(\mathrm{DCH})$ in pharmaceutical preparations were developed. These methods were based on diazotization-coupling reaction between diazotized o-nitroanline (DONA) and $\mathrm{DCH}$ in sodium carbonate medium to form yellow-orange colored azo dye product has a maximum absorbance at $448 \mathrm{~nm}$. Calibration graphs of absorbance versus concentration show that Beer's law were obeyed over the concentration ranges $0.4-52,5-200 \mu \mathrm{g} \mathrm{mL}^{-1}$ of DCH, with limit of detection of $0.284,1.117 \mu \mathrm{g} \mathrm{mL}^{-1}$ of $\mathrm{DCH}$ for batch and flow injection analysis (FIA) procedure respectively, and sample throughput was $171 \mathrm{~h}^{-1}$ for FIA method. All chemical and physical conditions affected on the developed colored product were carefully studied and the proposed methods were successfully applied for the determination of doxycycline in its pharmaceutical preparations.
\end{abstract}

Keyword: Diazotized o-nitroanline, Flow injection analysis, Doxycycline hyclate.

\section{1- Introduction}

Doxycycline hyclate (DCH) chemically named as $(4 S, 4 \mathrm{a} R, 5 S, 5 \mathrm{a} R, 6 R, 12 \mathrm{a} S)-4-$ dimethylamino)-3,5,10,12,12a-pentahydroxy6-methyl-1,11-dioxo- $\quad 1,4,4 \mathrm{a}, 5,5 \mathrm{a}, 6,11,12 \mathrm{a}$ octahydrotetracene-2-carboxamide hydrochloride hemiethanol hemihydrates and molecular weight 512.9 g.mol ${ }^{-1}$ Fig.(1). DCH more soluble than doxycycline monohydrate, this is one of the main reasons for it's more frequent use in pharmaceutical samples. DCH is one of the tetracycline derivatives has broad spectrum antibacterial agents effective against a host of Gram positive and Gram negative aerobic and anaerobic bacteria which obtained from oxytetracycline or metacycline. Doxycycline is preferred to other tetracyclines in the treatment of specific infections because of its fairly reliable absorption and its long half-time, it is used to treat chronic prostatic, Syphilis and pelvic inflammatory disease [1-2].

Several methods have been developed for determination $\mathrm{DCH}$ in pharmaceutical preparations such as spectrophotometric [3-6], high performance liquid chromatography HPLC [7,8], RP-HPLC [9], potentiometry[10], Chemliumincence [11] and thin layer Chromatography [12], however, some of these methods are time consuming and/or require expensive equipment.
The present paper describe development of batch and FIA methods which based and diazotization-coupling reaction between DCH and diazotized o-nitroaniline (DONA) reagent in sodium carbonate medium, yellow-orange azo dye was produced and spectrophotometrically measured at $448 \mathrm{~nm}$. Both batch and FIA procedures have applied for the determination DCH in its pharmaceutical preparations.

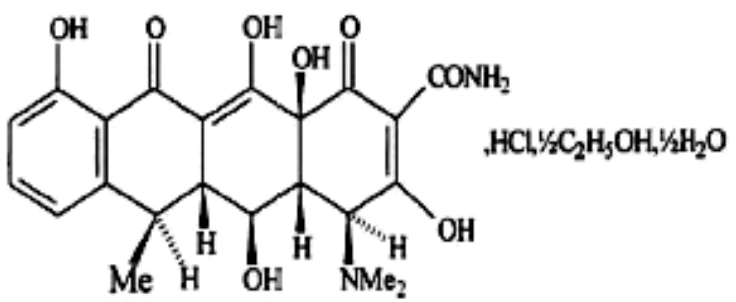

Fig.(1) structure of doxycycline hyclate.

\section{2- Materials and methods \\ 2-1: Apparatus}

All spectral and absorbance measurements were carried out by using a shimadzu UVvisible-260 digital double beam recording spectrophotometer (Tokyo-Japan), and using 1 $\mathrm{cm}$ quarts cells. A quartz flow cell with $50 \mu \mathrm{L}$ internal volume and $1 \mathrm{~cm}$ bath length used for the absorbance measurements. A two channel manifold Fig.(2) was employed for the FIA spectrophotometer determinations of DCH. A peristaltic pump (Ismatec Lobortechnik - 
Analytic, $\quad \mathrm{CH}-8512, \quad$ Glatbragg-Zurich, Switzerland, Sixchannels) was used to transport the reagents solutions. Injection valve (Rheodyne, Altex 210, supeko use) was employed to provide appropriate injection volumes of standard solutions and samples, flexible vinyl tubing of $0.5 \mathrm{~mm}$ internal diameter was used for the peristaltic pump. Reaction coil (RC) was of Teflon with internal diameter of $0.5 \mathrm{~mm}$. The diazotized $\mathrm{O}-$ nitroaniline (DONA) (A) stream was combined Fig.(2) with injected sample (DCH) and they merged with sodium carbonate (B) stream at $\mathrm{T}-$ link then mixed in reaction coil (RC) with length $(50 \mathrm{~cm})$, injection loop (200 $\mu \mathrm{L})$, total flow rate $2.5 \mathrm{mLmin}^{-1}$, the absorbance was measured at $448 \mathrm{~nm}$ at temperature $25 \mathrm{C}^{\circ}$.

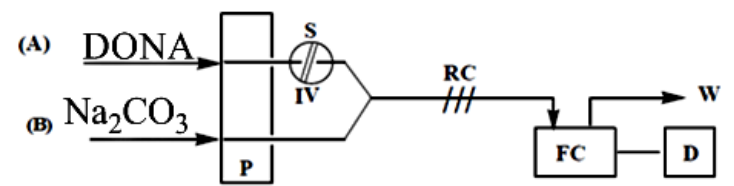

Fig.(2) A schematic diagram of FIA manifold where: $(A) \&(B)$, solutions of diazotized onitroaniline and sodium carbonate respectively; $P=$ peristaltic pump; $S=$ injection sample of $\mathrm{DCH} ; \mathrm{IV}=$ injection valve; $R C=$ reaction coil; $F C=$ flow cell; $D=$ detector; $W=$ waste.

\section{2-2: Reagents and materials}

Analytical reagents grade chemicals and distilled water were used thoroughly.

-Doxycycline hyclate stock solution

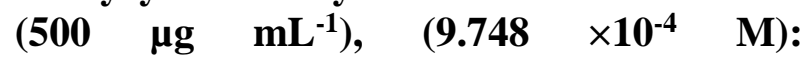
$0.05 \mathrm{~g}$ amount of pure DCH (SDI- Iraq) was dissolved in distilled water, and then completed to $100 \mathrm{~mL}$ in a volumetric flask with the same solvent. More dilute solutions were prepared by suitable dilution of the stock solution with distilled water.

-Hydrochloric acid (BDH-England)(1M): Was prepared by diluting $21.5 \mathrm{~mL}$ of 11.64 $\mathrm{M}$ of concentrated hydrochloric acid with distilled water in $250 \mathrm{~mL}$ volumetric flask, and standardized against $\mathrm{Na}_{2} \mathrm{CO}_{3}$.

\section{-Diazotized o-nitroanaline (DONA) $\left(10 \times 10^{-3} \mathrm{M}\right)$ :}

Was prepared daily by dissolving $0.138 \mathrm{~g}$ of o-nitroaniline (BDH-England) in $5 \mathrm{~mL}$ ethanol and add $20 \mathrm{~mL}$ of distilled water, then $6 \mathrm{~mL}$ of $\mathrm{HCl}$ (1M) was added. The mixture was transferred to $100 \mathrm{~mL}$ volumetric flask and placed in an ice-bath for $5 \mathrm{~min}$, then $0.069 \mathrm{~g}$ of sodium nitrite was added to the mixture and shacked well, After $5 \mathrm{~min}$, the volume was made up to the mark with distilled water. More dilute solutions were prepared by appropriate dilutions from stock solution with distilled water.

-Sodium carbonate (BDH-England) (0.3M): $7.948 \mathrm{~g}$ of sodium carbonate $\mathrm{Na}_{2} \mathrm{CO}_{3}$ was dissolved in a $250 \mathrm{~mL}$ volumetric flask with distilled water. $0.1 \mathrm{M}$ of sodium carbonate was prepared by dilution with distilled water.

\section{2-3:Pharmaceutical preparations of doxycycline \\ Pharmaceutical preparations were obtained from commercial sources. \\ 1- Doxycycline hyclate 8-capsules (Actavis- U.K.), each capsule contain $100 \mathrm{mg}$ of doxycycline.}

2- Medomycin 10-capsules (Medochemie Ltd.-cyprus), each capsule contain $100 \mathrm{mg}$ of doxycycline. $\mathrm{HCl}$.

3- Tabocine 10-capsules (Tabook- K.S.A.), each capsule contain $100 \mathrm{mg}$ of doxycycline hyclate.

\section{2-4: General procedure}

\section{2-4-1: General batch procedure}

Into a series of $25 \mathrm{~mL}$ volumetric flasks, an increasing volumes of $\mathrm{DCH}$ working solution $\left(100 \mu \mathrm{g} \mathrm{mL}^{-1}\right)$ were transferred to cover the range $0.4-52 \mu \mathrm{g} \mathrm{mL}^{-1}$ of calibration graph, $1 \mathrm{~mL}$ of DONA $\left(5 \times 10^{-3} \mathrm{M}\right)$ reagent was added, and followed by adding $1 \mathrm{~mL}$ of $\mathrm{Na}_{2} \mathrm{CO}_{3}$ $(0.1 \mathrm{M})$ for all flasks. The solutions were completed to the mark with distilled water, mixed well and left for $10 \mathrm{~min}$ at room temperature $\left(25 \mathrm{C}^{0}\right)$. The absorbance was measured at $448 \mathrm{~nm}$ versus the reagent blank was prepared in same way but without drug. A calibration graph was drawn and the statistical calculation was done for the analytical features obtained as shown in Table (1). For the optimization of conditions and in all subsequent experiments were carried out on $20 \mu \mathrm{g} \mathrm{mL}^{-1}$ of DCH. 


\section{2-4-2: General FIA procedure}

Working solution of $\mathrm{DCH}$ in the range 5$200 \mu \mathrm{g} \mathrm{mL}^{-1}$ was prepared from stock solution by appropriate dilution with distilled water. A $200 \mu \mathrm{L}$ portion of $\mathrm{DCH}$ was injected into the stream of DONA $\left(5 \times 10^{-3} \mathrm{M}\right)$ reagent and was then combined with a stream of $0.1 \mathrm{M}$ sodium carbonate with a total flow rate $2.5 \mathrm{~mL} \mathrm{~min}^{-1}$. A calibration graph was prepared and regression equation with other feature was calculated as shown in Table (1). Optimization of conditions was carried out on $40 \mu \mathrm{g} \mathrm{mL}^{-1}$ of DCH.

Table (1)

Analytical characteristics of the procedures for the determinations of DCH.

\begin{tabular}{|c|c|c|}
\hline Parameter & Batch method & FIA method \\
\hline Regression equation & $Y=0.0283 X+0.0134$ & $Y=0.0066 x-0.0064$ \\
\hline Linear range $\left(\mu \mathrm{g} \mathrm{mL}^{-1}\right)$ & $0.4-52$ & $5-200$ \\
\hline Correlation coefficient & 0.9993 & 0.9992 \\
\hline Limit of detection $\left(\mu \mathrm{g} \mathrm{mL}^{-1}\right)$ & 0.284 & 1.117 \\
\hline Average of recovery, $\%$ & 99.613 & 100.689 \\
\hline Relative standard deviation (RSD), \% & 1.528 & 0.739 \\
\hline Sandells Sensitivity $\left(\mu \mathrm{gcm}^{-2}\right)$ & 0.035 & 0.151 \\
\hline Through-put $\left(\mathrm{hr}^{-1}\right)$ & 6 & 171 \\
\hline Molar absorptivity $\left(\mathrm{L} \mathrm{mol}^{-1} \mathrm{~cm}^{-1}\right)$ & $14.515 \times 10^{3}$ & $3.385 \times 10^{3}$ \\
\hline
\end{tabular}

\section{2-5: Pharmaceutical preparation analysis}

An accurately weight amount of 10 powder capsules (100 mg of DCH pre each capsule). Equivalent to $50 \mathrm{mg}$ of the pure drug was transferred into $100 \mathrm{~mL}$ volumetric flask and completed to the mark with distilled water. The flask with its contents was shacked well and filtered to produce $500 \mu \mathrm{g} \mathrm{mL}^{-1}$ solution of DCH capsule. Deferent diluted concentrations were prepared by simple dilution with distilled water in $25 \mathrm{~mL}$ flasks final volume and used for analysis; the measurements were carried out as described earlier under general procedure.

\section{3: Results and Discussion}

\section{3-1:Batch spectrophotometric determination}

The factors affecting on the sensitivity of the colored product resulting from diazotization-coupling reaction between $\mathrm{DCH}$ and DONA reagent in basic medium were carefully studied. A typical spectrum for the yellow-orange azo dye formed was measured versus reagent blank which has absorbance at 448 nm Fig.(3).

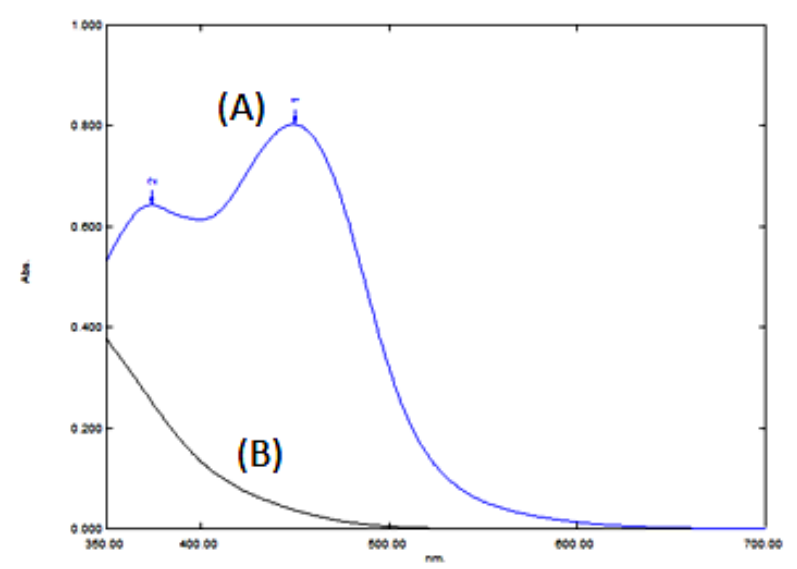

Fig.(3) Absorption spectra of the azo dye $\left(20 \mu \mathrm{g} \mathrm{mL}^{-1}\right)$ of doxycycline hyclate $(A)$ against reagent Blank $(B)$ and blank against distilled water.

The experimental conditions for the determination of DCH were established. The diazotization process occurred in an acidic medium and hydrochloric acid in concentration (1 M) was selected, the effect of 
different volumes of $\mathrm{HCl}$ were studied and $3 \mathrm{~mL}$ volume seem to be optimum for intense azo dye color produced after coupling with DCH as shown in Fig.(4), effect of the volume of DONA $\left(5 \times 10^{-3} \mathrm{M}\right)$ reagent was studied in the range $(1-5 \mathrm{~mL})$ and $1 \mathrm{~mL}$ was found to be optimum Fig.(4). The diazotization-coupling reaction occurred in an alkaline medium, thus, the effect of different alkaline solutions $(0.1 \mathrm{M})$ on the colored product was studied such as sodium hydroxide, ammonium hydroxide, sodium acetate and sodium carbonate. Maximum sensitivity and stability was obtained only when the reaction is carried out in the presence of $\mathrm{Na}_{2} \mathrm{CO}_{3}$. The effect of different volumes of sodium carbonate was studied in the range (1-10 mL), A volume of $1 \mathrm{~mL}$ was found enough to obtain a maximum absorbance Fig.(4), the order of addition of the reagents was studied and found that the order the order of addition cited under general procedure gave the maximum color intensity and minimum absorbance of the reagent blank and was used in all subsequent experiments. The effect of temperature on the color intensity of the dye was studied. In practice, high absorbance was obtained when the color was developed at room temperature $\left(25 \mathrm{C}^{\circ}\right)$ then when the volumetric flasks were placed in an ice-bath at $\left(0 \mathrm{C}^{\circ}\right)$ or in water bath $\left(45 \mathrm{C}^{\circ}\right)$. Experimental results revealed that the color intensity reach maximum after DONA had been reacted with $\mathrm{DCH}$ in the presence of $\mathrm{Na}_{2} \mathrm{CO}_{3}$ for a $10 \mathrm{~min}$, therefore a $10 \mathrm{~min}$ developed time was suggested as the optimum reaction time and remain stable for $120 \mathrm{~min}$.

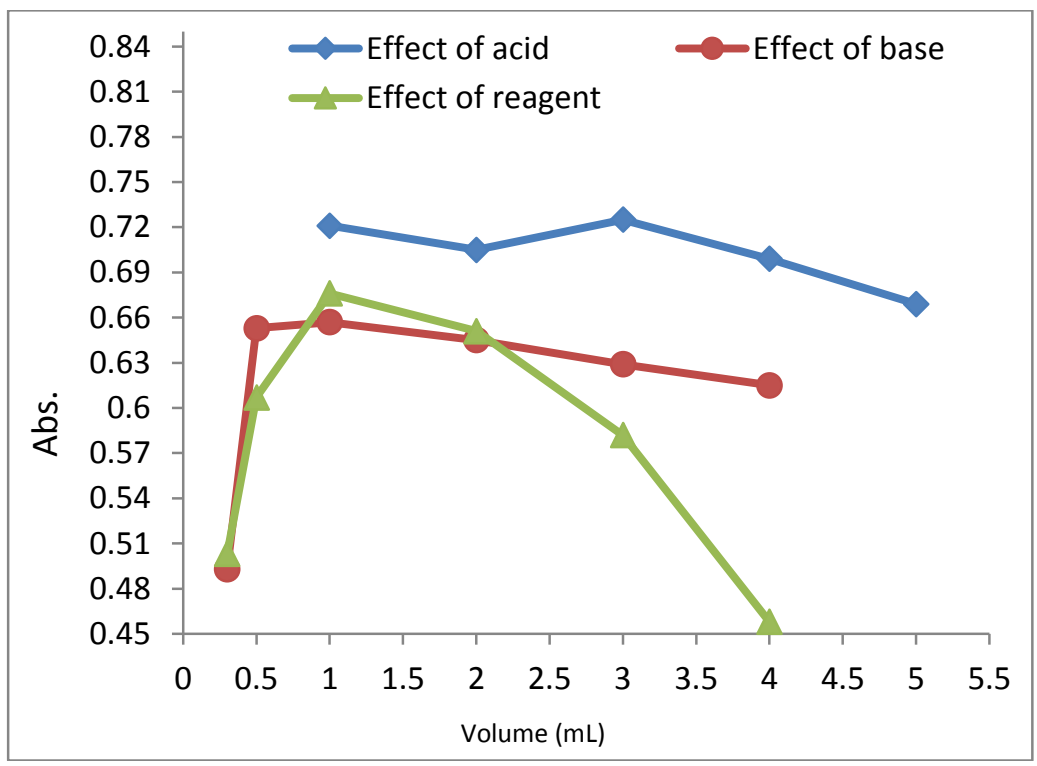

Fig.(4) Effect of different parameters on batch method.

The stoichiometry of the reaction between DCH and DONA was investigated using continuous variation and mole ratio methods [13]. Equal concentration $\left(4.875 \times 10^{-4} \mathrm{M}\right)$ were prepared for DCH and DONA reagent. In mole ratio an increasing volumes of DONA reagent were added to a $2 \mathrm{~mL}$ solution of $\mathrm{DCH}$ drug in a series of $25 \mathrm{~mL}$ volumetric flasks, followed by $1 \mathrm{~mL}$ of $0.1 \mathrm{M} \mathrm{Na}_{2} \mathrm{CO}_{3}$, the volumes were made up to the mark with distilled water, allowed to stand for $10 \mathrm{~min}$, and absorbance was measured at $448 \mathrm{~nm}$.

The Job method was applied by placing 0.5 to $8.5 \mathrm{~mL}$ of solution of $\mathrm{DCH}$ drug into a series of $25 \mathrm{~mL}$ volumetric flasks, this was followed by placing 8.5 to $0.5 \mathrm{~mL}$ of DONA reagent and $1 \mathrm{~mL}$ of $(0.1 \mathrm{M})$ of $\mathrm{Na}_{2} \mathrm{CO}_{3}$. The solutions were diluted to the mark with distilled water, allowed to stand for $10 \mathrm{~min}$; and absorbance was measured and results for both stoichiometric methods plotted as shown in Fig.(5) and show that a (1:2) azo dye was formed between DCH and DONA as shown in proposed reaction sequence in Fig.(6). The product was soluble in water and the apparent stability constant was calculated by comparing stoichiometric amount of DCH $\left(4.875 \times 10^{-4} \mathrm{M}\right)$ and DONA $\left(4.875 \times 10^{-4} \mathrm{M}\right)\left(\mathrm{A}_{\mathrm{s}}\right)$ with that of 
solution containing a ten-fold excess of DONA $\left(\mathrm{A}_{\mathrm{m}}\right)$ and the stability constant was calculated according to the following equations:

$k=\frac{1-\propto}{4 c^{2} \alpha^{3}}$ and $\propto=A_{m}-A_{s} / A_{m}$ the main performance of the flow procedure developed for $\mathrm{DCH}$ determination in order to make an effective comparison between the two approaches.

The analytical features of the procedure a summarized in Table (1). It also summarized
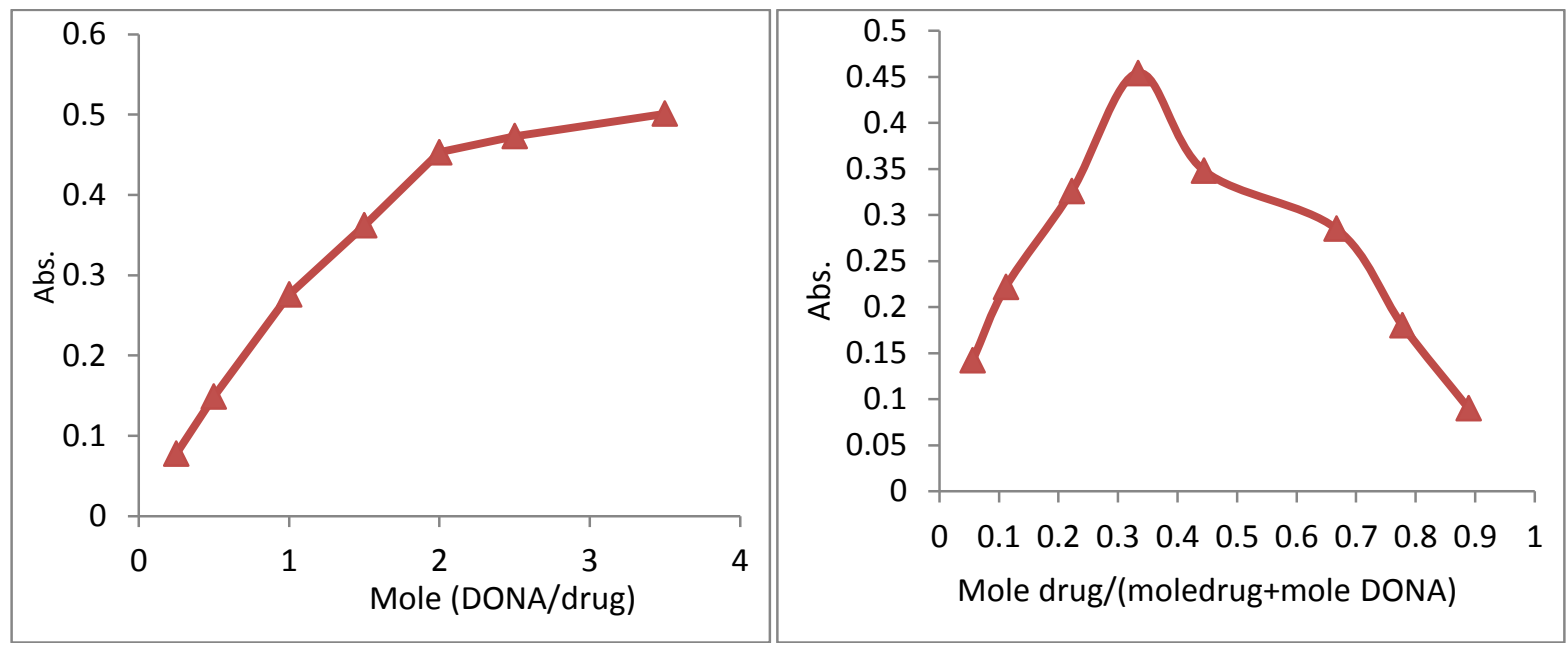

Fig.(5) Stoichiometric plots for colored dye products: mole ratio plot and continues variation plo.

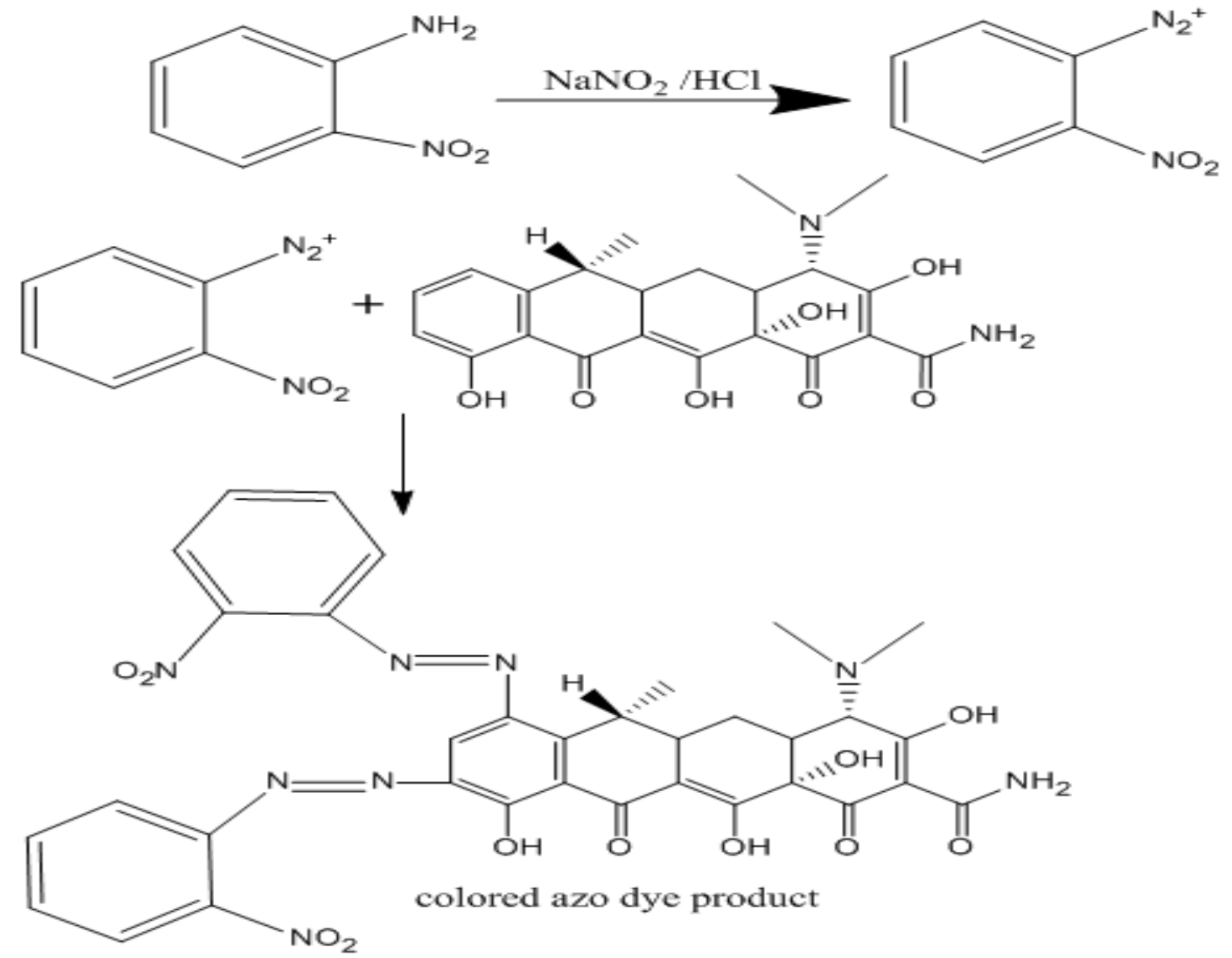

Fig.(6) Reaction sequence. 


\section{3-2: Flow-Injection spectrophotometeric determination}

The batch method for the determination of DCH was adopted as a basis to develop FIA procedure. The manifolds used for the determination of $\mathrm{DCH}$ was so designed to provide different reaction conditions for magnifying the absorbance signal generated by the reaction of DCH with DONA in sodium carbonate medium. Maximum absorbance intensity was obtained when the sample was injected into a stream of DONA and then with a stream of sodium carbonate $(0.1 \mathrm{M})$ as show above in Fig.(2). The influence of different chemical and physical FIA parameters on the sensitivity of the colored product was optimized as follows:

\section{3-2-1: Optimization of chemical parameters}

The effect of various concentrations of DONA $\left(1 \times 10^{-3}-10 \times 10^{-3} \mathrm{M}\right)$ was investigated. A concentration of $\left(5 \times 10^{-3} \mathrm{M}\right)$ DONA gave the highest absorbance and was chosen for further experiments as shown in Fig.(6). It was observed that the reaction between DONA and DCH depends on alkaline medium, thus, the effect of different concentrations $(0.05-0.3 \mathrm{M})$ of $\mathrm{Na}_{2} \mathrm{CO}_{3}$ was studied and $0.1 \mathrm{M}$ was found to be the optimum as shown in Fig.(7).

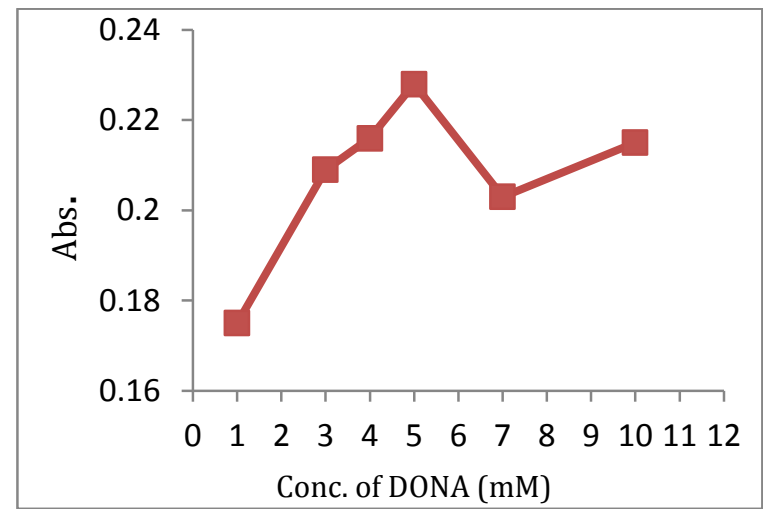

Fig.(6) Effect of concentration of DONA.

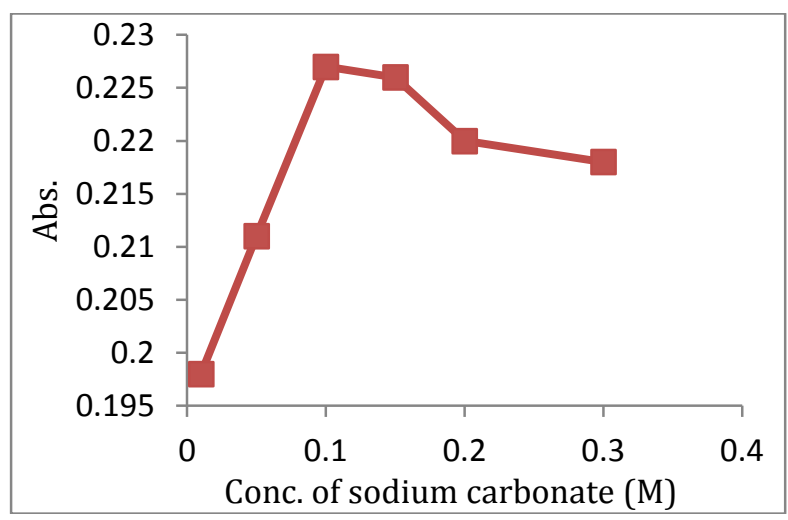

Fig.(7) Effect of concentration of $\mathrm{Na}_{2} \mathrm{CO}_{3}$.

\section{3-2-2: Optimization of physical parameters}

The effect of total flow rate on the absorbance intensity of the colored product was investigated in the range of (0.5$\left.4.0 \mathrm{~mL} \mathrm{~min}^{-1}\right)$. The results obtained show that a total flow rate of $2.5 \mathrm{~mL} \mathrm{~min} \mathrm{mave}^{-1}$ gave highest absorbance as shown in Fig.(8) and was used in all subsequent experiments.

The reaction coil length is an essential parameter that effects on the sensitivity of the colored reaction product and was investigated in the range of $25-250 \mathrm{~cm}$, the result obtained shoe that a reaction coil length of $50 \mathrm{~cm}$ gave the highest absorbance as shown in Fig.(9), and was used in all subsequent experiments.

The effect of the volume of injected sample was investigated by varying it between 100 and $250 \mu \mathrm{L}$ using different lengths of sample loop. The result show that injected sample of 200 portion gave the best absorbance with good reproducibility Fig.(10). The reaction time is also an important parameter that affected on the sample throughput and was investigated by calculating the interval time between the sample injection and the appearance of the maximum value of the signal. The reaction time of each sample was $21 \mathrm{sec}$; therefore, the sample throughput was 171 samples per hour.

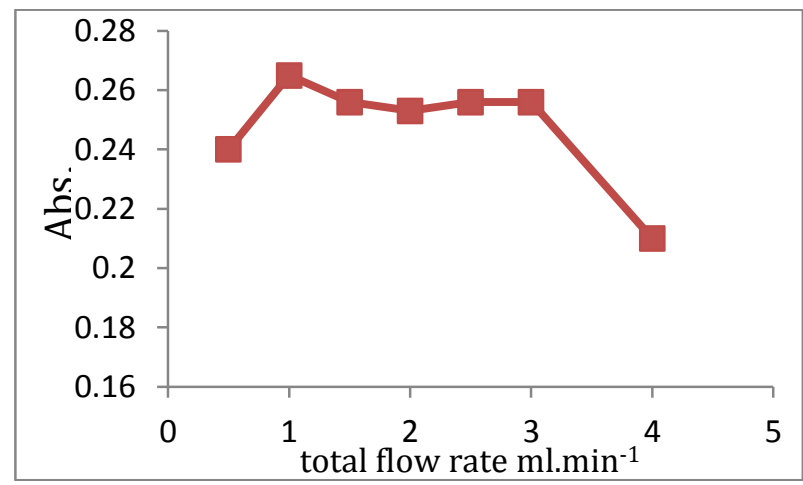

Fig. (8) Effect of total flow rate.

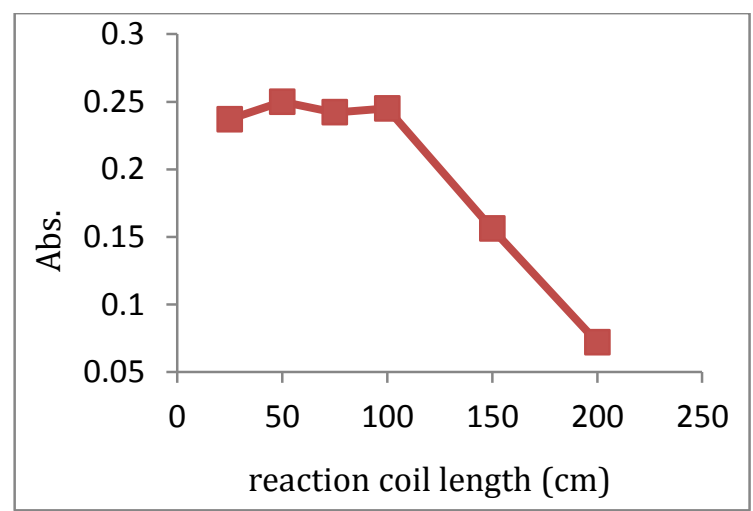

Fig.(9) Effect of reaction coil length. 


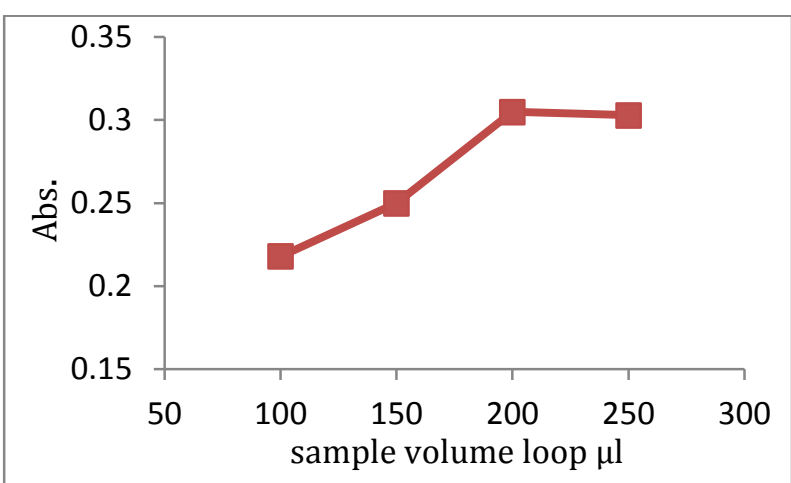

Fig.(10) Effect of injected sample volume.

A standard calibration line, obtained for a series of DCH standard and the main analytical feature of the developed method are indicated in Table (1). The accuracy and the precision Table (2) of the proposed method were studied by determinations of three different concentrations and equations results from calibration graphs Table (1) was applied for absorbance to find concentrations, and compared with result obtained from the standard method [2].

Table (2)

The accuracy and precision of the proposed methods (Batch and FI).

\begin{tabular}{|c|c|c|c|c|c|c|c|c|c|}
\hline \multicolumn{5}{|c|}{ Batch method } & \multicolumn{5}{|c|}{ Flow injection method } \\
\hline \multicolumn{2}{|c|}{ Conc. $\mu g . m L^{-1}$} & \multirow{2}{*}{$E \% *$} & \multirow{2}{*}{$\operatorname{Rec.} \%{ }^{*}$} & \multirow{2}{*}{$\underset{*}{R S D} \%$} & \multicolumn{2}{|c|}{ Conc. $\mu g . m L^{-1}$} & \multirow{2}{*}{$E \% *$} & \multirow{2}{*}{$\operatorname{Rec.\% }{ }^{*}$} & \multirow{2}{*}{$\begin{array}{c}R S D \\
\%^{*}\end{array}$} \\
\hline Present & Found & & & & present & found & & & \\
\hline 8 & 7.816 & -2.296 & 97.903 & 2.436 & 50 & 50.242 & 0.484 & 100.484 & 0.963 \\
\hline 16 & 16.212 & 1.325 & 101.325 & 1.228 & 100 & 102.939 & 2.393 & 102.393 & 0.897 \\
\hline 20 & 19.922 & -0.388 & 99.611 & 0.920 & 150 & 148.787 & -0.808 & 99.191 & 0.357 \\
\hline
\end{tabular}

\section{* For five determinations.}

\section{3-3: Analytical applications:}

The proposed methods were applied successfully to the analysis of some pharmaceutical preparations containing DCH. The results are summarized in Table (3) are in accordance with those obtained by the official

Table (3)

Applications of the proposed and official methods to the determinations of some TCH and DCH in pharmaceutical forms.

\begin{tabular}{|c|c|c|c|c|c|c|c|c|c|c|}
\hline \multirow{3}{*}{ Pharmaceuticals } & \multirow{3}{*}{$\begin{array}{c}\text { Conc. } \\
\text { MgmL }\end{array}$} & \multirow{3}{*}{$\begin{array}{l}\text { Found } \\
\text { MgmL }^{-1} \\
\end{array}$} & \multirow{3}{*}{ Rec. \%* } & \multirow{3}{*}{$\begin{array}{c}R S D \\
\% * \\
\end{array}$} & \multicolumn{4}{|c|}{ Flow injection analysis } & \multirow{2}{*}{\multicolumn{2}{|c|}{ Official method }} \\
\hline & & & & & \multirow{2}{*}{$\begin{array}{c}\text { Conc. } \\
\mu g m L^{-1} \\
\end{array}$} & \multirow{2}{*}{ 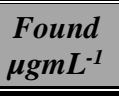 } & \multirow{2}{*}{ Rec.\%* } & \multirow{2}{*}{$R S D \% *$} & & \\
\hline & & & & & & & & & Rec.\%* & $\mathrm{RSD \%}^{*}$ \\
\hline $\begin{array}{c}\text { Medomycin } \\
\text { (DCH) } \\
\text { Capsule 100mg } \\
\text { (Kyprus ) }\end{array}$ & $\begin{array}{c}8.000 \\
16.000 \\
20.000\end{array}$ & $\begin{array}{c}7.808 \\
16.057 \\
19.750\end{array}$ & $\begin{array}{c}97.600 \\
100.357 \\
98.750\end{array}$ & $\begin{array}{l}3.844 \\
1.016 \\
1.498\end{array}$ & $\begin{array}{c}50 \\
100 \\
150\end{array}$ & $\begin{array}{c}51.260 \\
100.257 \\
151.390\end{array}$ & $\begin{array}{l}102.521 \\
100.257 \\
100.926\end{array}$ & $\begin{array}{l}0.695 \\
0.751 \\
1.522\end{array}$ & 101.583 & 1.364 \\
\hline $\begin{array}{c}\text { Doxycycline } \\
\text { (DCH) } \\
\text { Capsule 100mg } \\
\text { (actvas, UK) } \\
\end{array}$ & $\begin{array}{c}8.000 \\
16.000 \\
20.000\end{array}$ & $\begin{array}{c}7.952 \\
15.654 \\
19.919\end{array}$ & $\begin{array}{l}99.401 \\
97.841 \\
99.595\end{array}$ & $\begin{array}{l}1.982 \\
1.000 \\
1.505\end{array}$ & $\begin{array}{c}50 \\
100 \\
150\end{array}$ & $\begin{array}{c}49.393 \\
96.533 \\
147.116\end{array}$ & $\begin{array}{l}98.787 \\
96.533 \\
98.077\end{array}$ & $\begin{array}{l}0.894 \\
0.640 \\
1.515\end{array}$ & 102.286 & 0.776 \\
\hline $\begin{array}{c}\text { Tabocine }(\mathrm{DCH}) \\
\text { capsule100mg } \\
\text { (Tabok, K.S.A) }\end{array}$ & $\begin{array}{c}8.000 \\
16.000 \\
20.000 \\
\end{array}$ & $\begin{array}{c}8.003 \\
16.130 \\
20.164 \\
\end{array}$ & $\begin{array}{l}100.043 \\
100.815 \\
100.820 \\
\end{array}$ & $\begin{array}{l}1.872 \\
1.702 \\
1.468 \\
\end{array}$ & $\begin{array}{c}50 \\
100 \\
150 \\
\end{array}$ & $\begin{array}{c}51.239 \\
98.640 \\
150.748 \\
\end{array}$ & $\begin{array}{c}102.479 \\
98.640 \\
100.499 \\
\end{array}$ & $\begin{array}{l}0.850 \\
0.658 \\
1.118 \\
\end{array}$ & 99.627 & 2.181 \\
\hline $\mathrm{t}$ - test & \multicolumn{4}{|c|}{0.928} & \multicolumn{4}{|c|}{0.451} & \multicolumn{2}{|c|}{$\begin{array}{c}\text { (Thio.) } \\
2.447\end{array}$} \\
\hline $\mathrm{F}-$ test & \multicolumn{4}{|c|}{3.605} & \multicolumn{4}{|c|}{1.105} & \multicolumn{2}{|c|}{$\begin{array}{c}\text { (Thio.) } \\
9.28\end{array}$} \\
\hline
\end{tabular}

\footnotetext{
* For five determinations.
}

standard method. Finally, the statistical analysis [15] using F- and t- tests reveals that there is no significant difference in precision and accuracy between the proposed methods and the official methods. 


\section{4: Conclusion}

The developed methods are very adequate for determination of $\mathrm{DCH}$ in pharmaceutical preparations at race level concentration $\mu \mathrm{g} \mathrm{mL}{ }^{-1}$ and without requiring a temperature or PH control. In comparison of the batch with FIA procedure, the letter is more convenient then the former method because of its speed (sample throughput of 171 injection $\mathrm{h}^{-1}$ ) and wider linear range of the calibration graph.

The proposed method is thus, simple, rapid, and inexpensive and hence can be used in routine analysis of $\mathrm{DCH}$ in pharmaceutical preparations.

\section{Acknowledgements}

We would like to thank University of Baghdad, Collage of science, and the stuff of chemistry department for their providing the necessary facilities during the study

\section{References}

[1] Drollery E. (ED), "Therapeutic Drugs", $2^{\text {nd }}$, charchill livingstone, 1999.

[2] "British pharmacopeia", Stationary office, London, 2009.

[3] Ramesh P.J., Basavaiah K. and Rajen dtraprasad N., "Sensitive and selective spectrophotometric assay of doxycycline hhyclate in pharmaceuticals using folinciocatea reagent", Acta pharmaceuticals, 60, 445-454, 2010.

[4] Ramesh P.J., Bosavaiah K., Dorya M.R., Rejend raprasad N., Vinay K.B. and Revanasiddappa H.P., "Simple U.V and visible spectrophotometric methods for the determination of doxycycline hyclat in pharmaceuticals", Journal of Analytical chemistry, 66 (5), 482-489, 2011.

[5] Tella E.D., Taherunisa M., Deepthi V.K., Choragudi B.M. and choragudi B.R., "Sperctrophotometric determination of tetracyclines using $\mathrm{P}-\mathrm{N}, \mathrm{N}-$ dimethylphenoylenediamine and sodium metaperiodat, Russian Journal chemistry, 4(3), 539- 543, 2011.

[6] Masawat P., Liawmangrath S. and Updees., "Spectrophotometric flowinjection analysis assay of tetracycline antibiotics using adual light-emitting diode based detector", Maejo International journal of science and Technology", 2 (1), 201209, 2008.

[7] Mitic S.S, miletic G. Z., Kostic D.A., Naskovic-Dokic D.C., Arsic B.B. and Rasic I.D., "A rapid and reliable determination of doxycycline hyclate by HPLC with UV detection in pharmaceutical samples", Journal of the Serbian chemical society; 73 (6), 665-671, 2008.

[8] Mansor L and Darghonth J., "Determination of Tetracyclines in pure form and pharmacentical preparations by liquid chromatography", Journal of pharmaceutical and Biomedical analysis, 23, 353 - 362, 2000.

[9] Ramash J.P., Basavia L.K., tharpa. K., vinay K.B., Revanasiddappa H.D., "development and validation of RP - HPCL method for the determination of doxycycline hyclate in spiked human urine and pharmaceuticals", Journal of preclinical and clinical research, 4(2), 101107, 2010.

[10] Masawat, "Design and fabrication of electrochemical flow - through cell for determination of tetracycline antibiotics using FIA - Amperometry", Neresuan University science Journal, 3 (1), $1-6$, 2006.

[11] Aristoletelis A. and Syropoulos, "continuous-flow chemluimincence determination of some tetracycline", Frensenius Journal of analytical chemistry, 344, 128-130, 1992.

[12] Xie H., Dong C., Fen Y. and Liu C., "Determination of doxycycycline, tetracycline and oxytetracycline simultaneously by Tlc-flourcence scanning densitometry", Analytical Letters, 30 (1), 79-90, 1997.

[13] Braum R.D.,"Introduction to instrumental analysis", MC-Graw Hill, New York, 1987.

[14] Al-Abiachi M.Q., Al-Ghabsha T.S. and Salih E.S. "Application of promethazine hydrochloride as a chromogenic reagent for the spectrophotometric determination of anline and its substituents", Microchemistry Journal, 41, 64-72, 2009.

[15] Sanders D.H., Murph A.F., "Statistics", MC Graw-Hill, New York, 1976. 


\section{الخلاصة}

يتضمن البحث تطوير طرائق طيفية جديدة وحساسة

للتقدير المايكروغرامي للدوكسي سايكلين هيكلات في المستحضرات الصبدلانية باستخدام طريقتي الدفعة والحقن الجرياني. تعتمد هذه الطرائق على تفاعل الازوتة-ازدواج بين الاوثونايتروانيلين المؤزوت والدوكسي سايكلين في وسط قاعدي ليتكون لون اصفر -برتقالي من صبغة الاوزو الذائبة في الماء التي اعطت اعلى امتصاص عند 448 نانومتر . تشير منحنيات الامتصاص مقابل التركيز بان قانون بير ينطبق ضمن المدى 0.4-52 و 5-200 مايكروغرام مل-1 من الدوكسي سايكلين هيكلات وبحدود كثف 0.284 و 1.117 مايكروغرام مل-1 لكل من طريقتي الدفعة والحقن الجرياني على التوالي. وبمعدل نمذجة لطريقة الحقن الجرياني 171 نموذج في الساعة، بعد دراسة كافة المتغيرات الكيميائية والفيزيائية بدقة واختيار الظروف المنلى طبقت الطريقتين بنجاح في تقدير الدوكسي سايكلين في المستحضرات الصبدلانية. 